IJLR: International Journal of Law Recontruction

Volume 5, Number 2, September 2021

DOI : http://dx.doi.org/10.26532/ijlr.v5i2.17528

\title{
THE CREDIT RESTRUCTURING AS A FORM OF PROTECTION AGAINST CUSTOMERS DURING THE COVID-19 PANDEMIC
}

\author{
Rani Sri Agustina \\ Universitas Sultan Ageng Tirtayasa \\ rani@untirta.ac.id
}

\begin{abstract}
The submission of credit restructuring during the covid pandemic is a form of legal protection for customers who have difficulty paying credit. The COVID-19 stimulus policy in the banking sector was issued after observing developments in the economic impact related to the spread of COVID-19, which is still continuing globally and domestically. The approach method used is empirical juridical. The results of the research obtained stated that debtors who were affected by COVID-19, including micro, small and medium business debtors, were having difficulty fulfilling their obligations to banks, because the debtor or debtor's business was affected by the spread of COVID-19 either directly or indirectly to the economy. So far it has been running efficiently according to the restructuring agreement. The customer pays according to the agreement that has been made. Credit restructuring to maintain credit quality, which saves from bad credit.
\end{abstract}

Keywords: COVID-19; Credit; Customers; Pandemic; Protection; Restructuring.

\section{A. INTRODUCTION}

Economic development as part of national development, is an effort to realize the people's welfare fair and prosperous based on Pancasila and the Constitution of the Republic of Indonesia. ${ }^{1}$ Financial institutions are one of the important factors in economic development in Indonesia, especially to create the welfare of the Indonesian people. One of the bank's financial institutions is in the credit system, lending is one of the bank's business activities in banking in order to manage the funds under their control so that they are productive and can provide benefits. ${ }^{2}$

Based on Article 3 of Act No. 10 of 1998 Amendment to Act No. 7 of 1992 concerning Banking states that the main function of Indonesian banks is to collect and distribute funds. The law provides the understanding that banking is a financial intermediary institution tasked with collecting and distributing funds in the community to improve people's living standards. Banks are financial institutions that collect funds from the public and then distribute these funds to the public in the form of credit. Banks can provide

1 Lushun Adji Dharmanto, Perlindungan Hukum Kreditor Dengan Objek Hak Guna Bangunan Yang Berakhir Jangka Waktunya Sebelum Perjanjian Kredit Jatuh Tempo, Jurnal Pembaharuan Hukum, Vol III No. 2 May-August 2016, page.245-252

2 Thomas Suyatno, dkk, Kelembagaan Perbankan, Perbanas Gramedia, Jakarta 1988, page.11 
a variety of financing services, banks can also serve the needs of the community and businesses that use credit services to improve the quality of people's lives. Profit or profit is expected by the company to maintain its survival. One of the ways the company can make a profit is by providing credit to its customers. Credit is very important for profitability because with an increase or development of credit disbursed every year, it will also increase its profitability. In order to keep the profit of a company increasing, the credit disbursed must also be increased. In carrying out its operational activities, the bank has the main goal of achieving the maximum level of profitability. $^{3}$

Giving credit to the public through banking is of course carried out with a credit agreement between the giver and the credit recipient so that there is a legal relationship between the two, the credit agreement is usually made by the creditor, namely the bank, while the debtor only learns and understands it. ${ }^{4}$ Credit distribution or financing is the main activity in banking activities, including Rural Banks. Rural Banks, commonly abbreviated as BPR, are a type of bank known to serve micro, small and medium-sized entrepreneurs with locations that are generally close to where people are in need. With the existence of credit, the bank has the right to the performance of the borrower's customer so that it does not only pay off the debt but is also accompanied by a pre-agreed agreement. ${ }^{5}$

BPR has a very large role in developing the micro, small and medium enterprise (MSME) segment in Indonesia. The role of BPRs is not limited to that, because BPRs also contribute to increasing financial inclusion in Indonesia. It is recorded that BPR credit services to the public, including MSMEs, are around IDR 92.5 trillion, or growing $8.3 \%$ per year, so that BPRs are considered very potential to channel funds. Rural Banks are defined as banks that carry out business activities conventionally and/or based on sharia principles which in their activities do not provide services in payment traffic. BPR accepts deposits only in the form of time deposits, savings and/or other equivalent forms. BPR business activities are primarily aimed at serving small businesses and communities in rural areas. ${ }^{6}$

The COVID-19 outbreak has brought changes in the movement of the economic structure of society. ${ }^{7}$ The COVID-19 pandemic which also hit Indonesia, has made various sectors sluggish due to this pandemic, one of

3 Fauzan Haqiqi, Darmawan, Kasirul Fadli, Analisis Pengaruh Likuiditas Dan Pemberian Kredit Terhadap Tingkat Profitabilitas Pada Bank Bpr Mega Mas Lestari Tahun 2016-2018 Kabupaten Karimun, Jurnal Cafetaria, Vol. 1 No. 1 January 2020, page.73-83

4 Setyaningsih, Hidayat Abdulah, Anis Mashdurohatun, Peranan Notaris Dalam Pembuatan Akta Pemberian Hak Tanggungan (APHT) Terhadap Perjanjian Kredit Antara Kreditur Dan Debitur Dengan Jaminan Hak Tanggungan Di Purwokerto, Jurnal Akta, Vol 5 No 1 March 2018, page.187-196

5 Hermansyah, Hukum Perbankan Nasional Indonesia, Kencana Prenada Media Group, Jakarta, 2009, page. 56

6 Indria Widyastuti, Dewi Yuliandari, Analisis Peran Bank Perkreditan Rakyat (Bpr) Terhadap Peningkatan Kinerja Usaha Mikro Kecil (UMK), Cakrawala: Jurnal Humaniora Bina Sarana Informatika, Vol 16, No 2, 2016, page.1-12

7 Syafrida, Ralang Hartati, Bersama Melawan Virus Covid 19 di Indonesia, SALAM; Jurnal Sosial \& Budaya Syar-i, Vol. 7 No. 6 2020, page.495-508 
which is the economic and banking sectors, this is due to the reduced ability of debtors to carry out their obligations in paying credit installment obligations. The government has also taken special steps to improve economic conditions, especially for business actors today. In early March 2020, Indonesia started a war to deal with the Corona Virus (COVID-19) pandemic which began to enter Indonesia. Of course, with the first entry of the Corona Virus (COVID-19) in Indonesia, it will have an indirect impact on the Indonesian state, the most felt is the impact of the Indonesian economy. ${ }^{8}$ The spread of COVID-19 throughout the world, including Indonesia, has an impact on all areas of human life, including the economy. Then the Financial Services Authority issued the Financial Services Authority Regulation Number 11/POJK.03/2020 concerning National Economic Stimulus as a Countercyclical Policy for the Impact of the Spread of Corona Virus Disease 2019 (hereinafter referred to as POJK No. 11/2020). However, it should also be noted that the policy on restructuring/loaning/financing is left entirely to the policies taken by the Bank. In this case, the Bank that will handle it through a policy that contains the criteria for debtors and sectors affected by COVID-19 to then be entitled to the credit relief restructuring policy. ${ }^{9}$

The POJK for the extension of the COVID-19 stimulus policy in the banking sector was issued after observing developments in the economic impact related to the spread of COVID-19, which is still continuing globally and domestically. The regulator estimates that the pandemic will have an impact on the performance and capacity of debtors and increase bank credit risk. The Financial Services Authority (OJK) in March 2020 issued OJK Regulation Number 11/POJK.03/2020 concerning National Economic Stimulus as a Countercyclical Policy for the Impact of the Spread of Coronavirus Disease 2019 or POJK COVID-19 Stimulus. The regulation is valid until March 31, 2021 as a quick response and forward looking policy on the impact of the spread of COVID-19. With the issuance of POJK 48/POJK.03/2020, this stimulus policy will be in effect until March 31, 2022.

BPR Serang as a regional bank that has one mission as a driver of the community's economy has participated in restructuring, especially for micro, small and medium enterprises (MSMEs) who have the obligation to pay installments to the bank. This method is an option that can be chosen and implemented by BPR Serang as an effort to save non-performing loans so that they do not become bad loans which are feared to affect the smooth running of the bank's business. However, this does not necessarily mean that the community will receive credit relief, but must go through a process that has been determined by the OJK and the bank.

This restructuring is a form of legal protection for customers who have good intentions, because good faith underlies every agreement (Article

8 Mochamad Arifinal, Aris Suhadi, Rani Sri Agustina, Perlindungan Pekerja Buruh Terhadap Pemutusan Hubungan Kerja Pada Perusahaan Swasta Di Masa Pandemi Covid 19, Legal Standing Jurnal IImu Hukum, Vol.4 No.2, September 2020, page.290-300

9 Merry Tjoanda, Yosia Hetharie, Marselo Valentino Geovani Pariela, Ronald Fadly Sopamena, Covid-19 sebagai Bentuk Overmacht dan Akibat Hukumnya Terhadap Pelaksanaan Perjanjian Kredit, SASI, Vol 7 No 1 January- March 2021, page.93-101 
1338 paragraph (3) of the Civil Code) made by the parties in this case the agreement between the bank and the customer. Restructuring is a change in the terms of credit/financing concerning actions for adding bank funds and/or, the convention that all or part of the interest arrears becomes the principal of a new loan and/or the convention that all or part of the credit becomes an investment in the company, which can be accompanied by rescheduling and /or return requirements (restructuring). ${ }^{10}$

The restructuring gave birth to a renewal of the debt and receivable relationship, in which the debtor is obliged to repay the loan that has been given by the bank, based on the terms, conditions, and a predetermined payment period. The debtor must also have the awareness to pay his obligations if he feels able and has no difficulty in fulfilling his obligations. So that an agreement that has been made is not hampered by its implementation.

\section{B. RESEARCH METHODS}

This research is included in the type of empirical juridical research, or called field research, namely examining the applicable legal provisions and what happens in reality in society. ${ }^{11}$ Empirical juridical research is legal research regarding the enforcement or implementation of normative legal provisions in action on certain legal events that occur in society. ${ }^{12}$ Or in other words, that is a research conducted on the actual situation or real conditions that occur in the community with the intention of knowing and finding the facts and data needed, after the required data is collected then leads to problem identification which ultimately leads to problem solving. ${ }^{13}$

\section{RESULTS AND DISCUSSION}

\section{Credit Restructuring as a Form of Protection Against Customers During The COVID-19 Pandemic}

Bad credit in the banking world is a dangerous disease that can paralyze a bank. The problem of bad credit will not only harm the owners of the bank's shares, but will also harm the owners of funds, most of whom are members of the public. ${ }^{14}$ Credit originating from public funds must be disbursed with due observance of prudential principles and aspects of sound credit provision to avoid the risk of non-performing loans. Non-performing loans can cause potential losses to banks and disrupt economic and monetary stability. In other words, credit congestion will have an impact on the sustainability of national development that is being carried out because some funds are deposited

10 Ahmad Ifham Sholihin, Buku Pintar Ekonomi Syariah, Gramedia Pustaka Utama, Jakarta, 2010, page. 23

11 Suharsimi Arikunto, Prosedur Penelitiaan Suatu Pendekatan Praktek, Rineka Cipta, Jakarta, 2012, page. 126

12 Abdulkadir Muhammad, Hukum dan Penelitian Hukum, Citra Aditya Bakti, Bandung, 2004, page.134

13 Bambang Waluyo, Penelitian Hukum Dalam Praktek, Sinar Grafika, Jakarta, 2002, page.15

14 Gatot Supramono, Perbankan dan Masalah Kredit Suatu Tinjauan Yuridis, Djambatan, Jakarta, 1995, page.92. 
in bad loans. ${ }^{15}$

The rescue of non-performing loans is a step to resolve nonperforming loans through renegotiation between creditors and debtors. The negotiation in question is credit restructuring. The provision of credit is always carried out by applying the precautionary principle to avoid non-performing loans, but in reality there is no bank without nonperforming loans. ${ }^{16}$ In Bank Indonesia Regulation Number 14/15/PBI/2012 concerning Asset Quality Assessment of Commercial Banks, what is meant by credit restructuring is an effort to improve banks in credit activities for debtors who have difficulty fulfilling their obligations regulates in detail the methods that must be implemented by debtors and creditors in the implementation of debt restructuring. In practice, various types of debt restructuring implementation methods have developed which are mostly carried out by the community. ${ }^{17}$

The credit restructuring program is a bank policy in terms of supporting economic growth stimulus whose implementation still pays attention to bank risk management. The thing that needs to be considered in the restructuring process is the credit quality which has been determined to be smooth since the restructuring. Credit restructuring can be carried out on loans given before and after debtors are affected by the spread of COVID-19, including MSME debtors. ${ }^{18}$

The simplest and most common method of debt restructuring to be carried out in restructuring is the first by rescheduling or rescheduling, which is a change in credit terms that only involves changing the payment term. By rescheduling the payment of the debt, the creditor gives leeway to the debtor to pay the debt that has matured by delaying the due date. The second is the terms of return or reconditioning, namely changing part or all of the terms of the credit agreement. The amendment of these terms is not limited to only the term of payment, but involves any conditions as long as it does not add credit or convert all or part of the credit into company equity. The third is the method of implementing restructuring, namely restructuring or changing credit terms, which include: a. Additional funds; b. Conversion of all or part of debt arrears into new principal; c. rescheduling or return requirements. ${ }^{19}$

The restructuring aims to relieve creditors in the form of adjustments to principal installments, lower interest rates and time extensions. In addition to easing creditors, credit restructuring also maintains the liquidity of a bank, given the economic situation in the midst of a pandemic like this. The Financial Services Authority (OJK)

15 Yusuf Shopie, Perlindungan Konsumen dan Instrumen-Instrumen Hukumnya, PT.Citra Aditya Bakti, Bandung, 2000, page.34.

16 Hermansyah, Hukum Perbankan Nasional Indonesia, Kencana, Jakarta, 2005, page.76

17 Johanes Ibrahim, Cross Default \& Cross Collateral Sebagai Upaya Penyelesaian Kredit Macet, PT Refika Aditama, Bandung, 2004, page.117.

18 Lina Maya Sari, Luluk Musfiroh, Ambarwati, Restrukturisasi Kredit Bank Daerah X Pada Masa Pademi Covid-19, Jurnal Mutiara Madani, Vol 08 No. 1 July 2020, page.46-57

19 Muhamad djumhana, Hukum Perbankan Indonesia, Citra Aditya Bakti, Bandung, 1996, page.252. 
assesses that the stability of Indonesia's financial condition is still maintained thanks to a number of policies implemented, including Credit Restructuring or reduced installments in both banking and financing restructuring policy on loans taken by debtors. The credit provided by the bank uses the precautionary principle and the principle of trust so that the bank believes that the customer who is given credit is able to repay the loan and make installments in a timely manner. ${ }^{20}$ This effort is to maintain the stability of the financial services sector and provide space for the business sector and society to survive during the pandemic so as to accelerate the national economic recovery.

The Financial Services Authority, in connection with the outbreak of the corona virus (COVID-19) which has been designated as a pandemic and has caused disruption in almost all aspects of the economy, issued Financial Services Authority Regulation Number 11/POJK.03/2020 concerning the national economic stimulus. The purpose of the issuance of this POJK is to reduce the burden as a result of the COVID-19 pandemic on the community, especially MSMEs (although this POJK also applies to corporations). Implementation of restructuring:

a. Credit for Conventional Commercial Banks is carried out in accordance with the regulations of the Financial Services Authority regarding the assessment of the asset quality of commercial banks;

b. Financing for Islamic Commercial Banks and Sharia Business Units is carried out in accordance with the regulations of the Financial Services Authority regarding asset quality assessment of Islamic commercial banks and sharia business units;

c. Credit for Rural Banks is carried out in accordance with the regulations of the Financial Services Authority regarding the quality of productive assets and the establishment of allowance for write-off of productive assets of rural banks; or

d. Financing for Islamic Rural Banks is carried out in accordance with Financial Services Authority regulations regarding the quality of productive assets and the establishment of allowance for write-off of productive assets of Islamic rural financing banks.

After the issuance of this POJK, all banks and financial institutions have not responded to the POJK, so as a result, the POJK regarding the national economic stimulus has not been implemented properly and cannot immediately implement POJK Number 11/POJK.03/2020. This is not caused by financing companies or the banking world who do not comply with the POJK, but the substance of the POJK which is still multiinterpreted and does not apply as a final regulation.

The Financial Services Authority (OJK) extended the credit restructuring relaxation policy for one year until March 2022. This is an anticipatory step to buffer the decline in the quality of restructuring

20 Dhevi Nayasari Sastradinata, Bambang Eko Muljono, Analisis Hukum Relaksasi Kreadit Saat Pandemi Corona Dengan Kelonggaran Kredit Berdasarkan Peraturan Otoritas Jasa Keuangan Nomor 11/POJK.03/2020, Jurnal Sains Sosio Humaniora, Vol 4 No.2 2020, page.613-620 
debtors and maintain stability in the financial services sector. Previously, OJK set the relaxation policy through POJK No.11/POJK.03/2020 concerning National Economic Stimulus as a Countercyclical Policy for the Impact of the Spread of Coronavirus Disease. Then this policy was extended and the extension of the relaxation of credit restructuring aims to restore the economy, considering that the pandemic has not yet subsided, but the affected economy needs immediate recovery.

The Government through the Financial Services Authority issued the Financial Services Authorit y Regulation (POJK) Number 11/POJK.03/2020 concerning the National Economic stimulus as a Countercyclical Policy for the Impact of the Spread of the 2019 Coronavirus Disease, which is one of the Government's efforts to provide legal protection for people who have difficulty fulfilling their obligations in the credit agreement due to the COVID-19 pandemic.

The Constitution of the Republic of Indonesia based on Article $28 \mathrm{H}$ paragraph (1) states that everyone has the right to live in physical and spiritual prosperity, to have a place to live, and to have a good and healthy living environment and have the right to obtain health services. Then based on the provisions of Article 33 paragraph (3) of the 1945 Constitution, it is stated that: "The national economy is organized based on economic democracy with the principles of togetherness, efficiency, justice, sustainability, environmental insight, independence, and by maintaining a balance of progress and national economic unity."

Based on these provisions, during the 2019 Coronavirus Disease pandemic, the Government then issued regulations in order to protect health, including in order to protect the community's economy. One of the regulations that was later issued by the government based on the provisions of the 1945 Constitution was the issuance of the Financial Services Authority Regulation Number 11/POJK.03/2020 concerning the National Economic Stimulus as a Countercyclical Policy for the Impact of the 2019 Coronavirus Disease Spread.

Prior to the 2019 coronavirus disease pandemic, related to credit made by bank customers, there were special policies set by the Financial Services Authority. Through the Financial Services Authority Regulation Number 11/POJK.03/2015, there are provisions regarding credit restructuring. Credit restructuring is an improvement effort carried out by the Bank in credit activities for debtors who have difficulty fulfilling their obligations, which are carried out among others through: ${ }^{21}$
a. reduction in loan interest rates;
b. extension of Credit term;
c. reduction of loan interest arrears;
d. reduction of loan principal arrears;
e. addition of Credit facilities; and/or
f. conversion of Credit into temporary equity participation.

21 Pujiyono, M Najib Imannullah, Problematika Pelaksanaan POJK Nomor 45/POJK.03/2017 Dalam Penyelesaian Kredit Kecil dan Mikro Yang Macet Karena Bencana Alam, Jurnal IUS Kajian Hukum dan Keadilan, Vol 6 No. 3, December 2018, page.456-467 
Based on the provisions of Article 6 of POJK Number 11/POJK.03/2015, particularly in Article 6 paragraph (2), it has been stated that the application of credit and other provision of funds to MSMEs is in the amount of more than IDR 5,000,000,000 (five billion rupiah). is a restructured loan, and/or as a provision of funds to the 50 (fifty) largest debtors in each Bank. What is meant by the 50 (fifty) largest debtors are the 50 (fifty) largest debtors of the Bank individually. Based on the provisions of Article 7 of POJK Number 11/POJK.03/2015, the quality of loans that can be restructured, as stated in Article 7 paragraph (1) letter a, is for loans classified as doubtful or bad. Then as Article 7 paragraph (1) letter $b$ refers to loans classified as special attention or substandard. Thus, based on the POJK Regulation No. 11/POJK.03/2015, the provisions regarding credit restructuring are given to bank customers in terms of the criteria and quality of customer credit prior to restructuring, as regulated in Article 6 and Article 7.

The credit restructuring program is a bank policy in terms of supporting economic growth stimulus, the implementation of which is still taking into account the bank's risk management. The thing that needs to be considered in the restructuring process is the credit quality which has been determined to be smooth since the restructuring.

Restructuring based on the provisions of Article 2 of POJK Number 11/POJK.03/2020, especially in Article 2 paragraph (1) states "that debtors affected by COVID-19, including debtors of micro, small, and medium enterprises" who have difficulty fulfilling their obligations to the bank, because the debtor or debtor's business is affected by the spread of COVID-19, either directly or indirectly in the economic sector. Debtors who have met the requirements above can get credit restructuring or financing and/or provision of new funds. Credit restructuring is an improvement effort carried out by banks in credit activities for debtors who have difficulty meeting their obligations

The criteria for debtors who can receive the provision of new funds are debtors who are affected by the spread of coronavirus disease 2019 (COVID-19), including MSME debtors. As regulated in Article 7 Paragraph (1) which states that banks can provide new funds to debtors affected by the spread of COVID-19. For new credit and/or other provision of funds with a maximum ceiling of IDR $10,000,000,000.00$ (ten billion rupiah).

Based on the Financial Services Authority Regulation Number 11/POJK.03/2020 contained in Article 10, namely policies that support economic stimulus provided to debtors affected by the spread of COVID19 including micro, small and medium business debtors with a validity period of up to dated March 31, 2021. With the issuance of POJK 48/POJK.03/2020, this stimulus policy will be in effect until March 31, 2022.

From the description of the two regulations, the implementation of restructuring for debtors either before the COVID-19 pandemic or after the COVID-19 pandemic, the similarities between the two 
regulations are that they both provide restructuring policies to debtors, while the difference between the two Financial Services Authority Regulations, POJK Number 11/POJK.3/ 2015, the reason for issuing it is as a form of prudence in the context of national economic stimulus for commercial banks, and restructuring is given for loans classified as Doubtful or Loss, Under Special Mention, or Substandard. While POJK Number 11/POJK.0/2020 which has been amended by POJK $48 /$ POJK.03/2020 on the grounds that it is a countercyclical obligation due to the impact of the spread of coronavirus disease 2019 and restructuring is given to debtors affected by the spread of coronavirus disease 2019 (COVID-19), including micro, small and medium business debtors (Article 6).

Credit restructuring can be carried out on loans given before and after debtors are affected by the spread of COVID-19, including MSME debtors. The implementation of restructuring based on the POJK for Rural Banks is carried out in accordance with the regulations of the Financial Services Authority regarding the quality of productive assets and the establishment of an allowance for the write-off of productive assets of rural banks.

Provisions for credit must meet the following requirements: given to debtors affected by the spread of COVID-19 including MSME debtors; and restructured after debtors were affected by the spread of COVID-19, including MSME debtors. For debtors who are affected by the spread of COVID-19 including micro, small and medium business debtors with a maximum ceiling of IDR $10,000,000.00$ (ten billion rupiah) it can be based on the accuracy of payment of principal and/or interest or margin/profit sharing/ say goodbye.

The restructuring process at BPR Serang has complied with the requirements based on the OJK circular where customers or debtors are affected by COVID-19 with a credit value of below Rp 10,000,000,000.00 for informal workers, daily income, MSMEs, KUR. This policy is only valid for a maximum of 12 months and the last time customers and debtors apply to the bank. And then the banking sector again conducts the $5 \mathrm{C}$ analysis, namely character, capacity, capital, collateral, conditional of economy to see if the customer or debtor is eligible or not given credit restructuring.

The credit restructuring process that occurred at BPR Serang was carried out by extending the credit period and delaying credit installments along with reducing loan interest arrears in accordance with the results of the re-survey. Extending the period and delaying installment payments can minimize the burden on the debtor in fulfilling his obligations. This is because the debtor can choose a more flexible time to pay his installments to the creditor according to his ability according to the credit agreement agreed by both parties.

For example, the extension of the credit period is in the credit agreement No. 011/15488/BPR/PK/VIII/2019 between the First Party PT BPR Serang (Perseroda) and H. Ari Syamsudin as the first party due to a 
decrease in sales turnover due to the COVID-19 pandemic, after a resurvey was carried out, the BPR approved the request for restructuring a credit restructuring was conducted by changing the loan period from 24 (twenty four) months to 34 (thirty four) months so that there was a change in installments from IDR 2,643,600 (two million six hundred and thirty-six thousand rupiah) to IDR $1,523,994.01$ (one million five hundred twenty three thousand nine hundred nine four rupiah).

An example of a delay in credit installments is the restructuring of the credit agreement no. 581/01116010/BPR/PK/XI/2019 The first party PT BPR Serang (Perseroda) with Montartahan Maruli as the first party due to a decrease in sales turnover at his cafe due to the COVID-19 pandemic, after a re-survey was carried out, the BPR approved the request restructuring is a credit restructuring with a delay in credit installments which should have been 18 months starting from November 4, 2019 to May 4, 2019 to 14 months starting from July 7, 2020 to September 3, 2021 with the same installment amount of IDR 1,334,042 (one million three hundred thirty-four thousand and forty-two rupiah).

The process for applying for credit restructuring in general at BPR

Serang is as follows :

1. The customer comes to the bank to meet the account officer. The customer fills out the credit restructuring application form and brings the required files such as bank statements for the last 3 months, KTP of husband and wife, family card, marriage certificate, document/certificate from the company stating that there is a reduction in income and salary slips.

2. The bank's filing returns to the $5 \mathrm{C}$ analysis: Character is data about prospective customers (debtors) such as their nature and habits, Capacity (ability to repay debt) is the ability of the debtor to manage his business where the indicators in this assessment are the level of education, company history, Collateral (Guarantee) is a guarantee that can be confiscated if unable to pay, Capital (Capital) is the wealth owned and Conditional (Sikon) is considering economic conditions related to business projects.

3. Next, input is carried out through the banking system.

4. After that, the authorized official is verified.

5. Submission of collateral appraisal, where the bank assesses the collateral that has been guaranteed by the customer and the bank analyzes the collateral as feasible or not

6. Checking certificate, this is done to check to BPN whether the land or house is problematic or not, the name of the owner of the certificate is the same as the customer or not.

7. Approval officials, banking officials approve the application for credit restructuring.

8. Agreement, a new credit contract after credit restructuring.

Credit restructuring Impact of the spread of Corona Virus Disease 2019, this has legal consequences that the parties are obliged to carry out a restructuring agreement by delaying payments or extending the 
payment period, this is also in accordance with what is stated in Article 1338 paragraph (1) of the Indonesian Law Civil law, that a valid agreement that has been made will be considered a law for the parties who have made it.

Credit rescue through this restructuring can only be applied to debtors who are directly affected by COVID-19 who have difficulty paying installments, not to debtors who intentionally do not pay due to bad faith. This is regulated in Article 1244 of the Civil Code, namely:

"If there is a reason for that, the debtor must be punished to compensate for costs, losses and interest, if he cannot prove that the thing was not carried out or not at the right time for the implementation of the agreement, nor can he be held accountable for all of them, if bad faith does not exist on his part."

The submission of credit restructuring during the covid pandemic is a form of legal protection for customers who have difficulty paying. Legal protection for customers can be done in 2 ways, namely: first, indirect protection, namely legal protection provided to customers against all risks of loss that may arise as a result of a policy or bank business activities. Second, direct protection, namely direct protection of customers against possible risks of loss arising from business activities carried out by banks. ${ }^{22}$ This is because customers are consumers who are required to receive legal protection for the use of service products offered by banks. Legal protection is an effort to maintain and maintain the trust of the wider community, especially customers. ${ }^{23}$

The application of the legal protection concerns the criteria for debtors who meet the provisions of credit restructuring due to the COVID-19 pandemic in POJK 11/POJK. 03/2020, in Chapter III, concerning restructuring of credit or financing Article 5 and Article 6. In Article 5 Paragraph (1) ensuring that the quality of the restructured credit or financing is inaugurated, it is easy to try restructuring. This is one of the credit relaxation efforts during the COVID-19 pandemic, Article 5 Paragraph (2) banks can provide credit restructuring when debtors apply for credit to banks before or after the occurrence of the COVID-19 pandemic, but in the case of debtors applying for credit before the pandemic occurs credit or payment quality must be declared easy. The credit restructuring applies to small and medium enterprises (SMEs) and includes MSMEs as well, paragraph three where credit for Rural Banks and Islamic Rural Banks depends on the accounting treatment of each bank, Article 6 point $a$, is given to debtors who comply with the following provisions: Debtors affected by the COVID-19 pandemic include micro, small and medium business debtors, Article 6 point $b$, will be restructured after customers are declared affected by the onset of the COVID-19 pandemic including micro, small, and medium business customers, with the aim of making this regulation is considering that the

22 Hermansyah, Hukum Perbankan Indonesia, Op.Cit, page.154

23 Reza Aditya Pamuji, Perlindungan Hukum Bagi Nasabah dan Tanggung Jawab Bank Dalam Kasus Card Skimming, Lex Renaissance, Vol 3 No. 1 January 2018, page.25-43 
spread of COVID-19 is still happening both globally and nationally which of course has consequences for debtors and minimizes the risk of bad loans, therefore a regulation is made by the financial services authority to anticipate and optimize performance for banks and can maintain stability and be able to improve economic needs, but must prioritize and use the precautionary principle. ${ }^{24}$

In the context of discussing legal protection for customers with the regulations issued by the Financial Services Authority in the COVID19 situation, No.11/POJK.03/2020 concerning National Economic Stimulus as a Countercyclical Policy due to the impact of the spread of Coronavirus Disease 2019. Credit rescue can be carried out in three ways form, namely rescheduling by making changes to several terms of the credit agreement relating to the repayment schedule or credit term, including changes in the number of installments. Next is reconditioning, which is to make changes in part or all of the terms of the agreement without providing additional credit and without converting the participation. The last is restructuring (rearrangement) by making changes to credit terms in the form of providing additional credit or it can also be done by converting. Meanwhile, POJK 11/2020 saves credit during the Pandemic using a restructuring mechanism. ${ }^{25}$

Regulations issued by the government through the OJK are very helpful for debtors and banks or creditors to save all parties from the onslaught of the corona virus (COVID-19), both business actors as debtors and banks as creditors. So that in difficult situations, both parties must live together ${ }^{26}$.

\section{CONCLUSION}

The credit restructuring program based on POJK Number 11/POJK.03/2020, especially in Article 2 paragraph (1) states "that debtors affected by COVID-19, including debtors of micro, small, and medium enterprises" who have difficulty fulfilling their obligations to bank, because the debtor or debtor's business is affected by the spread of COVID-19, either directly or indirectly in the economic sector. So far it has been running efficiently according to the restructuring agreement. The customer pays according to the agreement that has been made. Credit restructuring to maintain credit quality, which saves from bad credit. If bad credit occurs, it will affect the bank's profit or even the bank suffers a loss. Restructuring is a legal protection effort given to debtor customers so that debtor customers must show good faith in the management and payment of bank credit resulting from credit restructuring due to the spread of COVID-19,

24 I Made Rai Sukerta, I Nyoman, Putu Budiartha, Desak Gde Dwi Arini, Restrukturisasi Kredit Terhadap Debitur Akibat Wanprestasi Karena Dampak Pandemi Covid-19, Jurnal Preferensi Hukum, Vol. 2, No. 2 July 2021, page.326-331

25 I Kadek Marchel Suarjana, Dientje Rumimpunu, Sarah D. L. Roeroe, Perlindungan Hukum Terhadap Debitur Dan Kreditur Dalam Situasi Covid-19, Lex Privatum, Vol. IX/No. 3/Apr/2021, page.5-14

26 Ong Argo Victoria \& Myska, Doctor's Constributions in Transportation Monitoring During COVID-19 Pandemic, KnE Social Sciences, Vol.5 No.1, 2021, page.598-618. 
because credit restructuring is not eliminating debtor obligations to debts to banks but is debt that must be paid through extension of payment period and delay of payment period. So that in every credit restructuring due to the impact of the COVID-19 pandemic, it is necessary to have consideration and prudence from the bank so that the provision of credit restructuring in the form of an extension of the installment period and a delay in the installment period given can hit the target and ensure timely loan repayments according to the restructuring agreement.

\section{Books}

\section{BLIBIOGRAPHY}

Abdulkadir Muhammad, 2004, Hukum dan Penelitian Hukum, Citra Aditya Bakti, Bandung;

Ahmad Ifham Sholihin, 2010, Buku Pintar Ekonomi Syariah, Gramedia Pustaka Utama, Jakarta;

Bambang Waluyo, 2002, Penelitian Hukum Dalam Praktek, Sinar Grafika, Jakarta;

Gatot Supramono, 1995, Perbankan dan Masalah Kredit Suatu Tinjauan Yuridis, Djambatan, Jakarta;

Hermansyah, 2005, Hukum Perbankan Nasional Indonesia, Kencana, Jakarta;

Hermansyah, 2009, Hukum Perbankan Nasional Indonesia, Kencana Prenada Media Group, Jakarta;

Johanes Ibrahim, 2004, Cross Default \& Cross Collateral Sebagai Upaya Penyelesaian Kredit Macet, PT Refika Aditama, Bandung;

Muhamad djumhana, 1996, Hukum Perbankan Indonesia, Citra Aditya Bakti, Bandung;

Suharsimi Arikunto, 2012, Prosedur Penelitiaan Suatu Pendekatan Praktek, Rineka Cipta, Jakarta;

Thomas Suyatno, dkk, 1988, Kelembagaan Perbankan, Perbanas Gramedia, Jakarta;

Yusuf Shopie, 2000, Perlindungan Konsumen dan Instrumen-Instrumen Hukumnya, PT.Citra Aditya Bakti, Bandung;

\section{Journals}

Dhevi Nayasari Sastradinata, Bambang Eko Muljono, Analisis Hukum Relaksasi Kreadit Saat Pandemi Corona Dengan Kelonggaran Kredit Berdasarkan Peraturan Otoritas Jasa Keuangan Nomor 11/POJK.03/2020, Jurnal Sains Sosio Humaniora, Vol 4 No.2 2020;

Fauzan Haqiqi, Darmawan, Kasirul Fadli, Analisis Pengaruh Likuiditas Dan Pemberian Kredit Terhadap Tingkat Profitabilitas Pada Bank Bpr Mega Mas Lestari Tahun 2016-2018 Kabupaten Karimun, Jurnal Cafetaria, Vol. 1 No. 1 January 2020; 
I Kadek Marchel Suarjana, Dientje Rumimpunu, Sarah D. L. Roeroe, Perlindungan Hukum Terhadap Debitur Dan Kreditur Dalam Situasi COVID-19, Lex Privatum, Vol. IX/No. 3/Apr/2021;

I Made Rai Sukerta, I Nyoman, Putu Budiartha, Desak Gde Dwi Arini, Restrukturisasi Kredit Terhadap Debitur Akibat Wanprestasi Karena Dampak Pandemi COVID-19, Jurnal Preferensi Hukum, Vol. 2, No. 2 July 2021;

Indria Widyastuti, Dewi Yuliandari, Analisis Peran Bank Perkreditan Rakyat (Bpr) Terhadap Peningkatan Kinerja Usaha Mikro Kecil (UMK), Cakrawala: Jurnal Humaniora Bina Sarana Informatika, Vol 16, No 2 2016;

Lina Maya Sari, Luluk Musfiroh, Ambarwati, Restrukturisasi Kredit Bank Daerah X Pada Masa Pademi COVID-19, Jurnal Mutiara Madani, Vol 08 No. 1 July 2020;

Lushun Adji Dharmanto, Perlindungan Hukum Kreditor Dengan Objek Hak Guna Bangunan Yang Berakhir Jangka Waktunya Sebelum Perjanjian Kredit Jatuh Tempo, Jurnal Pembaharuan Hukum, Vol III No. 2 May-August 2016;

Merry Tjoanda, Yosia Hetharie, Marselo Valentino Geovani Pariela, Ronald Fadly Sopamena, COVID-19 sebagai Bentuk Overmacht dan Akibat Hukumnya Terhadap Pelaksanaan Perjanjian Kredit, SASI, Vol 7 No 1 January- March 2021;

Mochamad Arifinal, Aris Suhadi, Rani Sri Agustina, Perlindungan Pekerja Buruh Terhadap Pemutusan Hubungan Kerja Pada Perusahaan Swasta Di Masa Pandemi COVID-19, Legal Standing Jurnal IImu Hukum, Vol.4 No.2, September 2020;

Ong Argo Victoria \& Myska, Doctor's Constributions in Transportation Monitoring During COVID-19 Pandemic, KnE Social Sciences, Dubai-Uni Emirates Arab (UEA), Vol.5 No.1, 2021;

Pujiyono, M Najib Imannullah, Problematika Pelaksanaan POJK Nomor 45/POJK.03/2017 Dalam Penyelesaian Kredit Kecil dan Mikro Yang Macet Karena Bencana Alam, Jurnal IUS Kajian Hukum dan Keadilan, Vol 6 No. 3, December 2018;

Reza Aditya Pamuji, Perlindungan Hukum Bagi Nasabah dan Tanggung Jawab Bank Dalam Kasus Card Skimming, Lex Renaissance, Vol 3 No. 1 January 2018;

Setyaningsih, Hidayat Abdulah, Anis Mashdurohatun, Peranan Notaris Dalam Pembuatan Akta Pemberian Hak Tanggungan (APHT) Terhadap Perjanjian Kredit Antara Kreditur Dan Debitur Dengan Jaminan Hak Tanggungan Di Purwokerto, Jurnal Akta, Vol 5 No 1 March 2018;

Syafrida, Ralang Hartati, Bersama Melawan Virus COVID-19 di Indonesia, SALAM; Jurnal Sosial \& Budaya Syar-i, Vol. 7 No. 62020. 